\title{
The Characteristics of Bribe-Taking by Chinese High-Level Officials
}

\author{
Huaiyuan Han, Lotfi Hamzi, Edgar Bellow \\ NEOMA Business School, Reims, France
}

\begin{abstract}
The purpose of this paper is to analyze in detail the characteristics of bribe-taking by provincial and ministerial or senior-level officials. In this paper, we analyze the data concerning all provincial and ministerial level officials convicted of bribe-taking apart from army generals. We identify 110 cases between 1987 and the end of 2015, of which 76 cases involved bribery alone and the rest also involved other crimes. The achievements of China's economic reforms and opening-up over the last 40 years are obvious to all, but they have encouraged significant problems of corruption by senior party and government officials. Between 1987 and 2015 the number of officials convicted of corruption grew significantly and, sentences became more severe. Since 1987, the amount of bribery has increased steadily and the time span of corruption has increased. Corrupt officials mostly use traditional kinds of exchange of interests, and corruption in China has spread into every part of society. China still has a long way to go if it is to win the fight against corruption.
\end{abstract}

Keywords: China, corruption, power, self-interest

\section{Introduction}

China is undergoing unprecedented change, which requires us to advance our understanding of this country constantly. To understand China well, it is necessary to investigate not only the factors that will promote its further economic development, but also those that could hinder its social progress.

Thirty years of reform and liberalization have brought China substantial increases in living standard together with corruption at different levels due to the lure of material gain and the imperfect legal system (Liang, 1994; Dong \& Torgler, 2013). Studies of this increasingly serious problem of corruption can give foreign investors, among others, a better understanding of China's society and investment environment.

Faced with growing bribery, the Chinese government has taken a series of anti-corruption measures (Gong, 1994; Yao, 2002). Since the 18th National Congress of the Chinese Communist Party (CPC) on November 8 , 2012, the CPC authorities and the Chinese government led by Xi Jinping have increased the intensity of its investigation of corruption cases against officials, especially high-ranking, to an unprecedented level (Guo \& Li, 2015). By the end of 2015, more than 120 provincial and ministerial level officials had been removed from their positions (News Xinhua, 2016).

Huaiyuan Han, Ph.D., professor, NEOMA Business School, Reims, France.

Lotfi Hamzi, Ph.D., professor, NEOMA Business School, Reims, France.

Edgar Bellow, Ph.D., professor, NEOMA Business School, Reims, France.

Correspondence concerning this article should be addressed to Huaiyuan Han, 3 allée des Crayères, Bezannes 51430, France. 


\section{Research Objectives}

In China, the crime of bribe-taking is defined by Article 385 of Chinese Criminal Code as "state officials who take advantage of their office to demand money or goods from other people, or who illegally accept money or goods from other people and give favors in return” (Criminal Law of the People's Republic of China, 1997).

Our research will focus on the detailed characteristics of bribe-taking by provincial and ministerial or senior-level officials. It will consider only public officials, including staff in the Chinese Communist Party (CPC), government, legislature, judiciary, and state-owned enterprises (SOEs), who have been convicted by the courts and whose sentences have been officially announced.

\section{Methodology}

In this paper, we analyze all provincial and ministerial level officials convicted of bribery (or more precisely, of bribe-taking) apart from army generals. We identified 110 cases between 1987 and the end of 2015, of which, 76 cases involved bribery alone (for example, in 2011, Huang Sheng, former Deputy Governor of Shandong Province, was convicted of bribery) and the rest also involved other crimes (for example, in 2005, Liu Jinbao, former President of Bank of China (Hong Kong), was convicted of bribery, embezzlement and misappropriating public funds).

To obtain more precise results, in the case of multiple crimes, we only consider the part of the sentence for bribery. For example, in the case of Liu Jinbao, we only considered the 12 years of imprisonment for bribery in our analysis, although he was sentenced to death suspended for two years. However, when it was impossible to obtain information about the specific conviction for bribery in a case, we did not include this case in our analysis of average time span of case of bribery of Chinese high-level officials. For example, Xu Jinbao was found guilty of various crimes between 1993 and 2003, but information about when he took bribes is unavailable.

Through an analysis of 110 cases of bribery, our research reveals the features of bribe-taking by Chinese provincial and ministerial level officials.

\section{Data Analyses}

\section{Area Distribution of the Convicted Officials}

Beside 20 cases that occurred in various central ministries and agencies and 11 cases in state-owned enterprises, the other 79 cases are widely distributed between different provinces, autonomous regions or cities, except Tibet.

Table 1

Corrupt Officials Almost All Over the Country

\begin{tabular}{ll}
\hline Region & Number of cases \\
\hline \multirow{2}{*}{ East } & 28 (Beijing 3; Tianjin 2; Hebei 2; Shanghai 1; Jiangsu 3; Zhejiang 3; Fujian 3; Shandong 4; Guangdong \\
Center & 5; Hainan 2) \\
West & 26 (Shanxi 1; Anhui 4; Jiangxi 6; Henan 2; Hubei 4; Hunan 2) \\
North-East & Gansu 1; Qinghai 1; Ningxia 2; Xinjiang 1) \\
\hline
\end{tabular}




\section{Trends in Number of Convictions (1987-2015)}

Apart from victims of political struggles within the party, almost no any provincial and ministerial level officials were punished because of corruption in the 30 years following the founding of the People's Republic of China. Although the Tianjin Party Secretary and Shijiazhuang Vice Party Secretary were sentenced to death for corruption in 1952, there were only bureau-level officials.

In February 1987 Hong Qingyuan, former Secretary-General of the Party Committee of Anhui Province, was sentenced to 10 years' imprisonment for bribery. He is considered the first provincial and ministerial level cadre sentenced for corruption.

The number of provincial and ministerial level officials convicted of bribery increased from one case in 1987 to 16 cases in 2015, presenting a clear upward trend.

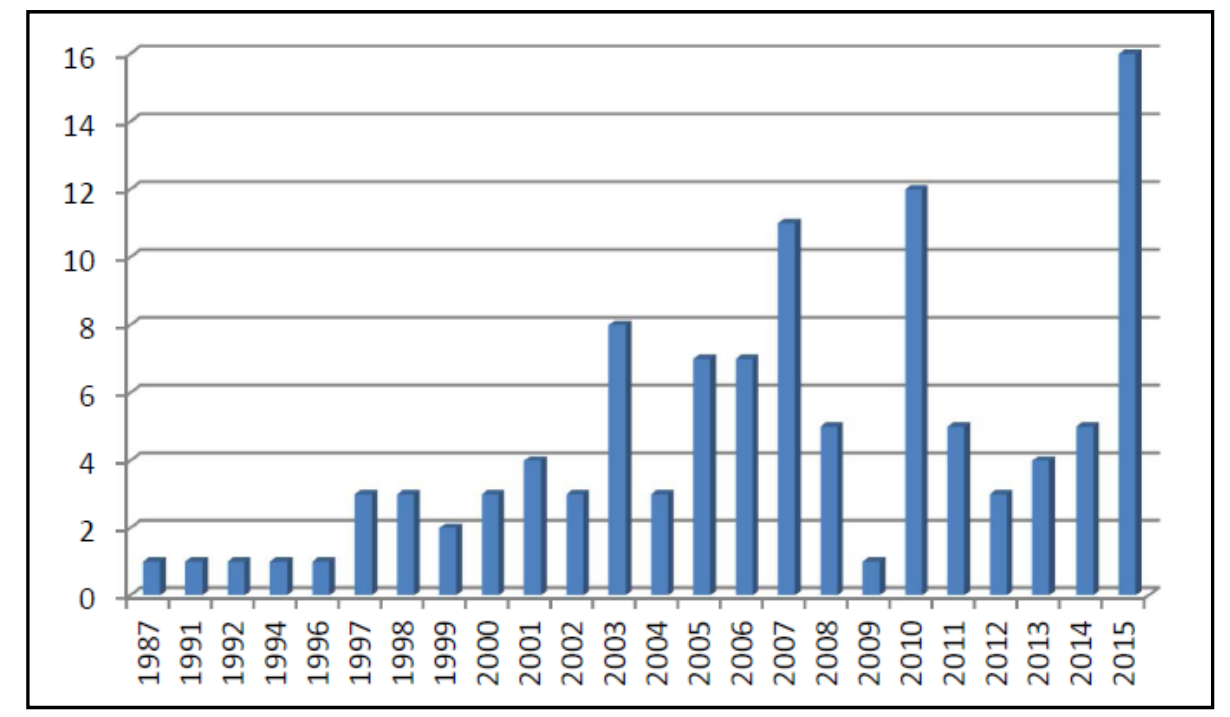

Figure 1. Number of officials sentenced.

\section{Sentences Received (Only for the Crime of Taking Bribes)}

In 1999, for the first time in the history of Chinese Communist Party's anti-corruption measures, a provincial/ministerial official, Xu Bingsong, sentenced to life imprisonment for the crime of bribe-taking. In 2000, a provincial/ministerial level official, Cheng Kejie, was condemned to death, an unprecedented sentence for bribery. In 2001, the first senior official convicted of taking bribes, Li Jizhou, who received a suspended death sentence. However, the data collected show us that from the beginning of the 21st century, the CPC and the Chinese government significantly increased their efforts to combat the bribery of senior officials.

Table 2

Sentences in Different Period

\begin{tabular}{lllll}
\hline Period & Set term of imprisonment & Life imprisonment & Suspended death sentence & Death penalty \\
\hline $1987-1990$ & 1 & 0 & 0 & 0 \\
$1991-1995$ & 3 & 0 & 0 & 0 \\
$1996-2000$ & 9 & 1 & 0 & 2 \\
$2001-2005$ & 15 & 4 & 5 & 1 \\
$2006-2010$ & 11 & 7 & 17 & 1 \\
$2011-2015$ & 17 & 10 & 6 & 0 \\
\hline
\end{tabular}




\section{Last Position}

According to our data, the 110 dismissed officials occupied 35 different positions. Forty-five of the cases are concentrated on three positions (Vice-governor, Vice-chairman of the Standing Committee of the Provincial People's Congress and Vice-chairman of the provincial CPPCC); the rest are widely distributed among different positions.

Otherwise, we can find that the 110 last posts are mainly distributed in the following areas:

Table 3

Sectors of Corrupt Officials' Last Position

\begin{tabular}{ll}
\hline Sector & Number of case \\
\hline Central CPC and Government Departments & 17 \\
Provincial and Municipal CPC and Government Departments & 75 \\
Central Judicial Departments & 1 \\
Provincial and Municipal Judicial Departments & 5 \\
State-Owned Financial Enterprise & 5 \\
State-Owned Non-financial Enterprise & 7 \\
\hline
\end{tabular}

\section{Crimes Committed}

Of the 110 cases, 76 resulted in conviction for the crime of bribery alone. In the remaining 34 cases, the convictions were for one or more other offenses in addition to bribery.

Table 4

Distribution of Charges

\begin{tabular}{ll}
\hline Charges & Number of case \\
\hline Bribe taking & 76 \\
Bribe taking + (1) & 9 \\
Bribe taking + (2) & 8 \\
Bribe taking + (3) & 5 \\
Bribe taking + (4) & 2 \\
Bribe taking + (5) & 2 \\
Bribe taking + (1) + (2) & 1 \\
Bribe taking + (1) + (6) & 1 \\
Bribe taking + (1) + (7) & 1 \\
Bribe taking + (1) + (3) & 1 \\
Bribe taking + (3) + (2) & 1 \\
Bribe taking + (3) + (5) & 1 \\
Bribe taking + (2) + (7) & 1 \\
Bribe taking + (9) + (10) & 1 \\
\hline
\end{tabular}

Notes. (1) Holding a huge amount of property from unidentified sources; (2) Abuse of authority; (3) Corruption; (4) Dereliction of duty; (5) Misappropriating public funds; (6) Causing explosions; (7) Offering bribes; (8) Deliberately leaking state secrets; (9) Making false accusations; (10) Illegal business operations.

\section{Time-Span of Corruption (Taking Bribes)}

For each case, as the following example shows, it's possible to find the duration of the crime.

The Court’s Judgment for Zhu Zuoyong, former Vice-chairman of Gansu Province CPPCC:

Upon trial, the court found that from April 1994 to September 2004, the defendant Zhuzuo Yong used his position as 
Vice-chairman of Gansu Province CPPCC and Mayor of Lanzhou City to seek benefits for others and illegally accept money and goods of a total value of RMB 170 million.

Two of the 110 cases were not included when calculating the time-span of the crimes:

Hong Qingyuan, due to lack of necessary information.

Zhou Yongkang, due to lack of necessary information.

The average time-span for the 108 cases was 97.02 months (8.08 years).

The following table and graph compare the average time-span of taking bribes in the different periods.

Table 5

Average Time-Span of Bribe-Taking (108 Cases) in the Different Periods

\begin{tabular}{ll}
\hline Period & Average time-span of bribe-taking (in months) \\
\hline $1991-1995$ & 33.33 \\
$1996-2000$ & 30.50 \\
$2001-2005$ & 70.76 \\
$2006-2010$ & 113.47 \\
$2011-2015$ & 135.18 \\
\hline
\end{tabular}

One of the total 76 cases was not included in the calculation of the time-span: the case of Hong Qingyuan, due to a lack of necessary information.

The average time-span for the 75 cases of bribe-taking was 92.32 months (7.69 years).

The longest time-span was the case of Yang Baohua, former Chairman of Hainan Province CPPCC: 216 months (18 years).

The shortest time-span was the case of Hou Wujie, former Vice-secretary of Shanxi Province: two months (0.16 years).

Table 6

Average Time-Span of Bribe-Taking (75 cases) in the Different Periods

\begin{tabular}{ll}
\hline Period & Average time-span of bribe-taking (in months) \\
\hline $1991-1995$ & 34.00 \\
$1996-2000$ & 29.72 \\
$2001-2005$ & 63.89 \\
$2006-2010$ & 114.63 \\
$2011-2015$ & 131.73 \\
\hline
\end{tabular}

Whether bribe-taking was the only crime involved or other crimes were also involved, the time-span of the crimes has become steadily longer.

\section{The Administrative Positions in Which the Exchanges of Interest Occurred}

Depending on the time span of the crime, officials may carry out the exchange of interests in different administrative positions. Our study reveals in what positions illegal exchange of interest can be conducted.

The analysis included 109 cases in all, but the ones we omitted were included in the analysis except the case of Zhou Yongkang due to a lack of detailed information.

We find that of the 109 cases, 72 cases involved two or more positions, and the highest number was 10 in the case of Chen Anzhong, former Deputy Director of Jiangxi Province People’s Congress. 
Table 7

Most Corrupt Officials Involved Two or More Positions

\begin{tabular}{ll}
\hline Number of administrative positions & Number of cases \\
\hline 1 & 37 \\
2 & 23 \\
3 & 23 \\
4 & 15 \\
5 & 9 \\
6 & 1 \\
10 & 1 \\
\hline
\end{tabular}

Our research shows that the illegal exchange of interest occurred in 61 different positions.

Table 8

Position in Which Illegal Exchanges Occurred

\begin{tabular}{|c|c|}
\hline Position & Number \\
\hline Secretary of municipal CPC committee & 31 \\
\hline Mayor & 30 \\
\hline Vice-governor & 24 \\
\hline Deputy secretary of municipal CPC committee & 12 \\
\hline Secretary of prefectural Party committee & 10 \\
\hline President of State owned enterprise & 10 \\
\hline Vice-chairman of provincial СРРСС & 9 \\
\hline Vice-chairman of standing committee of Provincial People’s Congress & 8 \\
\hline Vice-minister & 8 \\
\hline Managing director of State-owned enterprise & 8 \\
\hline Vice-secretary of the provincial Party committee & 8 \\
\hline Deputy mayor & 8 \\
\hline Director of provincial bureau & 7 \\
\hline Deputy director of bureau & 6 \\
\hline Chairman of standing committee of municipal people's congress & 6 \\
\hline Head of ministry department & 5 \\
\hline Provincial Standing Committee Member & 5 \\
\hline Minister & 4 \\
\hline Deputy director of provincial Bureau & 4 \\
\hline President of bank & 4 \\
\hline Vice-secretary of the prefectural Party committee & 3 \\
\hline Vice-president of bank & 3 \\
\hline President of provincial higher people’s court & 3 \\
\hline Secretary of provincial discipline inspection commission & 3 \\
\hline Chairman of provincial CPPCC & 3 \\
\hline Vice-president of State-owned enterprise & 3 \\
\hline Secretary-general of provincial Party committee & 3 \\
\hline Governor & 3 \\
\hline Assistant minister & 3 \\
\hline Assistant governor & 2 \\
\hline Prefect & 2 \\
\hline
\end{tabular}


(Table 8 to be continued)

Head of provincial CPC department

2

Deputy secretary-general of provincial Party committee

Chairman of bank

Acting mayor

Director of bureau

Others

In fact, one official can carry out illegal interest exchange of interest in different positions, for example Chen Anzhong, former Deputy Director of People’s Congress of Jiangxi Province, committed crimes in 10 different administrative posts: Deputy Secretary of Hengyang; Deputy Mayor of Hengyang; Mayor of Hengyang; Deputy Secretary of Jingdezhen; Mayor of Jingdezhen; Secretary of Pingxiang; Secretary of Jiujiang; Vice-chairman of Jiangxi Province CPPCC; Deputy Director of Jiangxi Province People's Congress of; Vice-chairman of Jiangxi Province Federation of Trade Unions.

\section{The Amount of Bribes Taken}

The average sum taken in bribes in the 110 cases was 13.23 million yuan. The smallest sum involved was 22,000 yuan, in the cases of Han Fucai and Zhang Xintai, sentenced respectively in 1991 and 1992, and the highest amount was 195.73 million yuan, in the case of Chen Tonghai, sentenced in 2010. We find that the average amount of bribes taken increased significantly between 1987 and 2015.

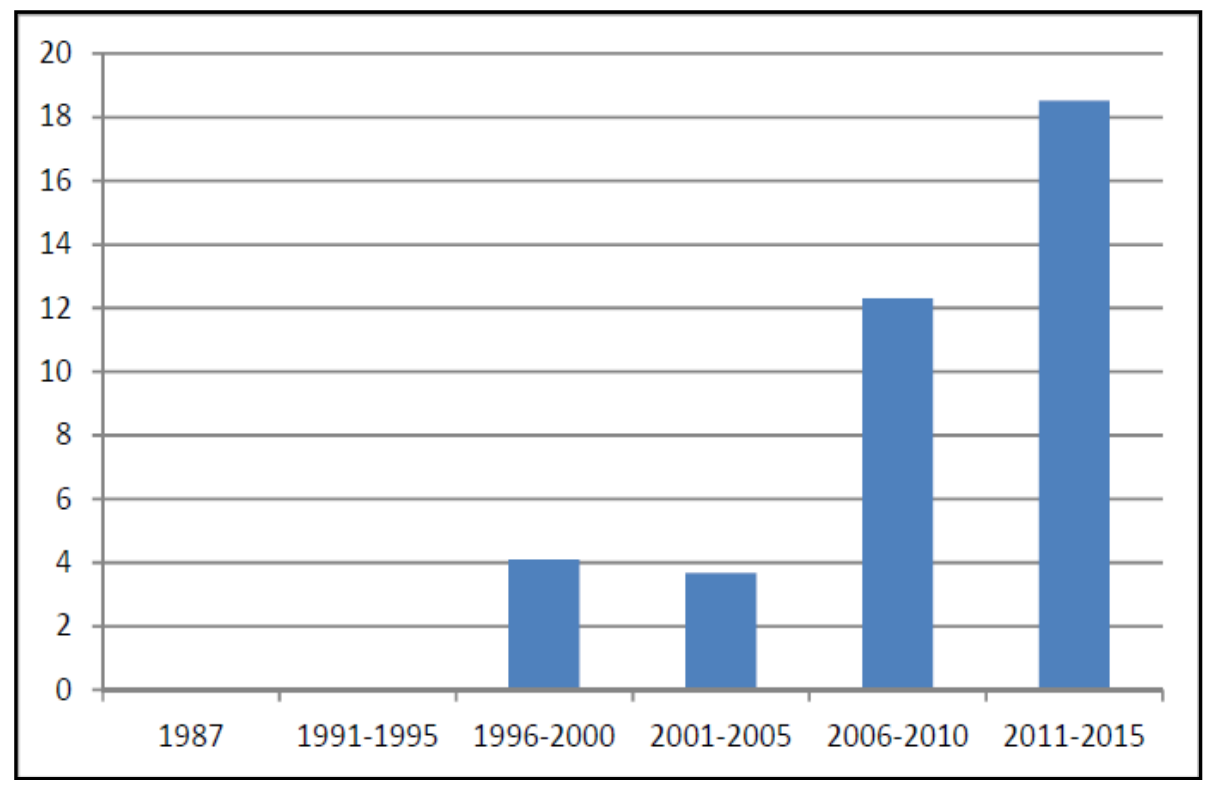

Figure 2. The average amount of bribes increased significantly between 1987 and 2015.

\section{Favors Provided in Return for Bribes}

Bribery is an exchange of money for official power. In return for the bribe, officials gave favors to their bribers. Our analysis of 110 cases shows that more than 30 different types of favors were provided in return for bribe, mainly focusing on job promotion or transfers, contract work, enterprise operation, bank loans and corporate and individual avoidance of judicial accountability. 
Table 9

Favors Provided in Return for Bribes

\begin{tabular}{ll}
\hline Favors provided & Case number \\
\hline Job promotion and job transfer & 47 \\
Contract work & 39 \\
Enterprise operation & 29 \\
Corporate bank loan & 26 \\
Commercial land use approval & 11 \\
Avoidance of legal action against companies and individuals & 8 \\
Land transfer procedures & 5 \\
Loan guarantee & 5 \\
Support for corporate government subsidies & 4 \\
Support for corporate fund raising & 3 \\
Corporate restructuring & 3 \\
Change in construction planning & 2 \\
Replacement of assets & 2 \\
Tax arrears & 2 \\
Taking advantage of position to seek benefits for others & 2 \\
Share transfer & 2 \\
Revolving fund & 2 \\
Passport or certificate for Hong Kong or Macao & 2 \\
Others & 17 \\
\hline
\end{tabular}

\section{Concluding Remarks}

The achievements of China's economic reforms and opening up over the last 40 years are obvious to all, but they have encouraged significant problems of corruption by senior party and government officials. This is one of the main reasons why the new Chinese Communist Party leadership (CCP) led by President Xi Jinping launched an anti-corruption campaign as soon as he took over as party chief at the end of 2012 (Liu, 2016).

Our study reveals that between 1987 and 2015 the number of officials convicted of corruption grew significantly and that sentences became more severe. In fact, since the beginning of this century, the Chinese ruling authorities have gradually increased the intensity of the fight against corruption. In addition to the weight of public opinion, the major reason is the risk that the evil of corruption in political and economic life could lead to the collapse of the regime.

China is a socialist country with a long history of bureaucratic culture (Gong, 1994). "Bureaucrats managing state assets, the sales of these assets and social development programs take advantage of such power to benefit themselves" (Chow, 2006). As the party relies on bureaucracy to manage the centrally planned and hierarchically ordered economy, bureaucrats are becoming a powerful social class even though the party has placed many constraints on them (Gong, 1994).

Our research reveals that the amount of bribery in China has increased steadily since 1987. In parallel with this trend, the average loss of social wealth in each corruption case has become more and more substantial (Yao, 2002).

The fact that the time span of corruption in China is increasing shows us that many senior officials have obtained promotion though hadden corruption (带病提拔 Dài bìng tíbá, Sick promoted) and that the senior official supervision mechanism is inadequate. 
Apart from in Tibet, corrupt officials are widely throughout China in every province, autonomous region, and directly-controlled city. This feature of corruption shows that the corruption is not restricted to economically developed coastal areas or remote poverty-stricken areas.

Some corrupt officials hold important positions such as governor and mayor, while others hold what are considered in China as sinecures, such as heads of provincial and municipal People's Congress and CPPCC. Officials in the national ministries and in departments under the party central committee are just as corrupt as local corrupt officials. Similarly, judicial officials are just corrupt as those in charge of the allocation of the economic resources. Corruption in China seems to "have spread into the Party, into Government administration and into every part of society, including politics, economy, ideology and culture” (Liang, 1994).

The result of our research confirms the views of Dong and Torgler (2013) that since launch of economic reforms, corruption has become even more widespread and exists at every level of China's political system.

Corrupt officials mostly use the traditional forms of exchange of interests. In other words, in the context of an imperfect system of legal supervision and a shortage of economic resources, officials use their power to help enterprises or individuals with problems such as promotion and job transfer, commercial land use rights, work contracts, bank loans and corporate operations in exchange for cash. The facts tell us that rent-seeking is one of the most common sources of corruption in today's China (Ngo, 2008).

Despite of the introduction of severe punishments and tough measures against corruption have been introduced by the party and the regime, "China has not really achieved its goal of anti-corruption” (Dai, 2010), and "it still has a long way to go before success can be achieved" (Guo \& Li, 2015).

If China wants to win the battle against corruption, it must above all enhance people's awareness of the law (Chow, 2006) and establish a system of democracy.

\section{References}

Chow, G. C. (2006). Corruption and China’s economic reform in the early 21st century. International Journal of Business, 11(3), 265-282.

Dai, C. Z. (2010). Corruption and anti-corruption in China: Challenges and countermeasures. Journal of International Business Ethics, 3(2), 58-71.

Dong, B., \& Torgler, B. (2013). Causes of corruption: Evidence from China. China Economic Review, 26, 152-169.

Gong, T. (1994). The politics of corruption in contemporary China: An analysis of policy outcomes. Westport: Praeger Publishers.

Guo, Y., \& Li, S. F. (2015). Anti-corruption measures in China: Suggestions for reforms. Asian Education and Development Studies, 4(1), 7-23.

Liang, G. (1994). The practical encyclopaedia of anti-corruption in China and foreign countries. Beijing: Xinhua Press.

Liu, E. (2016). A historical review of the control of corruption on economic crime in China. Journal of Financial Crime, 23(1), 4-21.

Ngo, T. W. (2008). Rent-seeking and economic governance in the structural nexus of corruption in China. Crime, Law and Social Change, 49, 27-44.

Yao, S. (2002). Privilege and corruption: The problems of China's socialist market economy. American Journal of Economics and Sociology, 61, 279-299. 